\title{
Posting the Canadas
}

\author{
Kyo Maclear
}

\section{Cartes postales adressées aux deux solitudes}

Une série de cartes postales sont publiées dans un quotidien, sont envoyées à des lecteurs inconnus. Ces cartes de Kyo Mclear n'affirment rien de positif au sujet de l'identité nationale canadienne mais signalent plutôt l'activité artificielle grâce à laquelle un semblant d'unité est maintenue. Envoyées par la narratrice aux différents relais de son voyage à travers sa mémoire, ces missives rappellent quelques-unes des occasions où elle fut témoin des tentatives d'établir l'idée d'une "canadiennités: à sept ans, pendant le cours de français, à un poste de douane, aux chutes Niagara. À bord, non pas d'un avion de la compagnie d'aviation nationale, mais $d^{\prime}$ 'un «avion origami», la narratrice nous donne la «preuve» que sa propre identitén'est viable que sous la forme d'un cliché. 


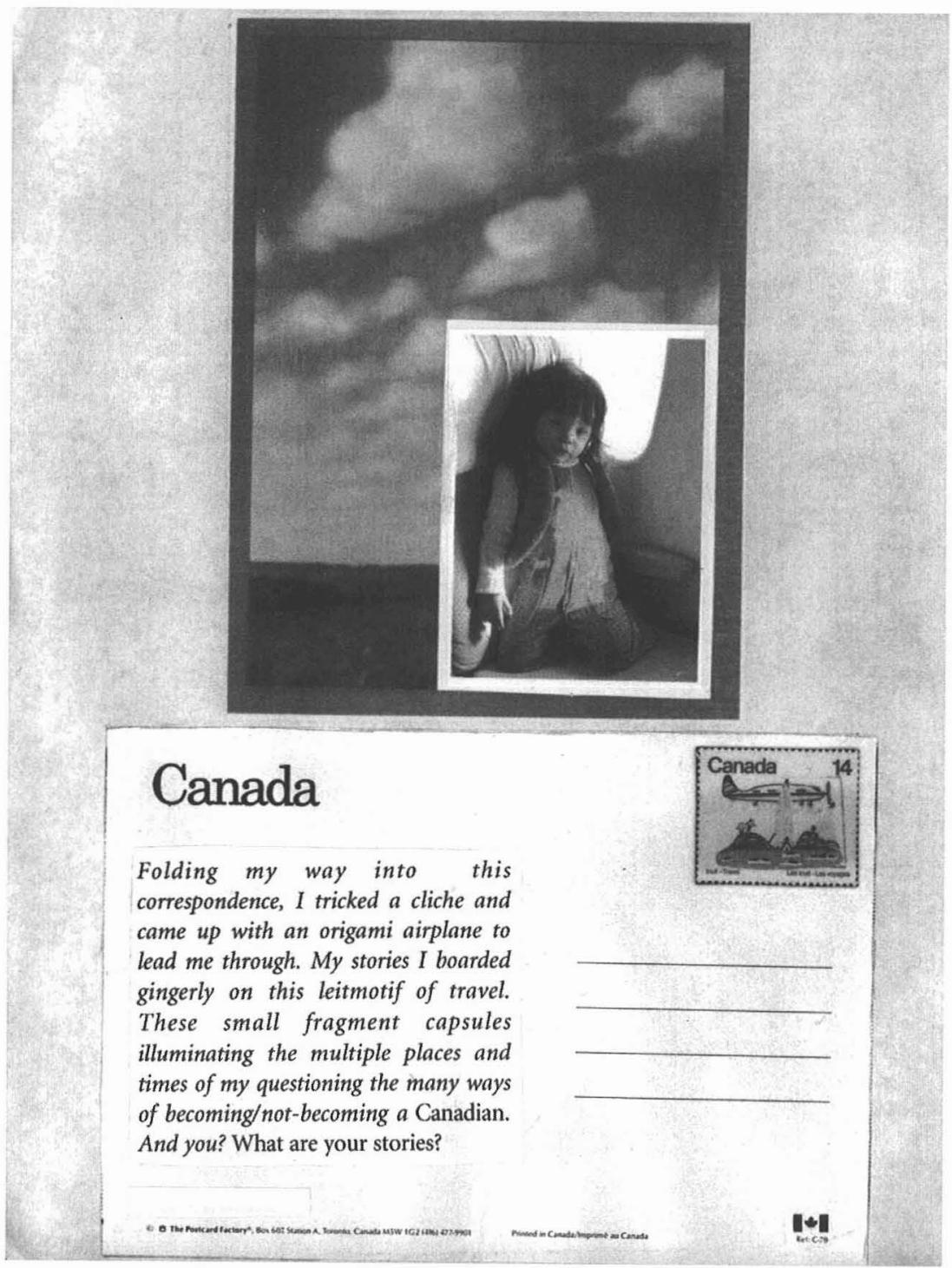


Posting the Canadas · 13

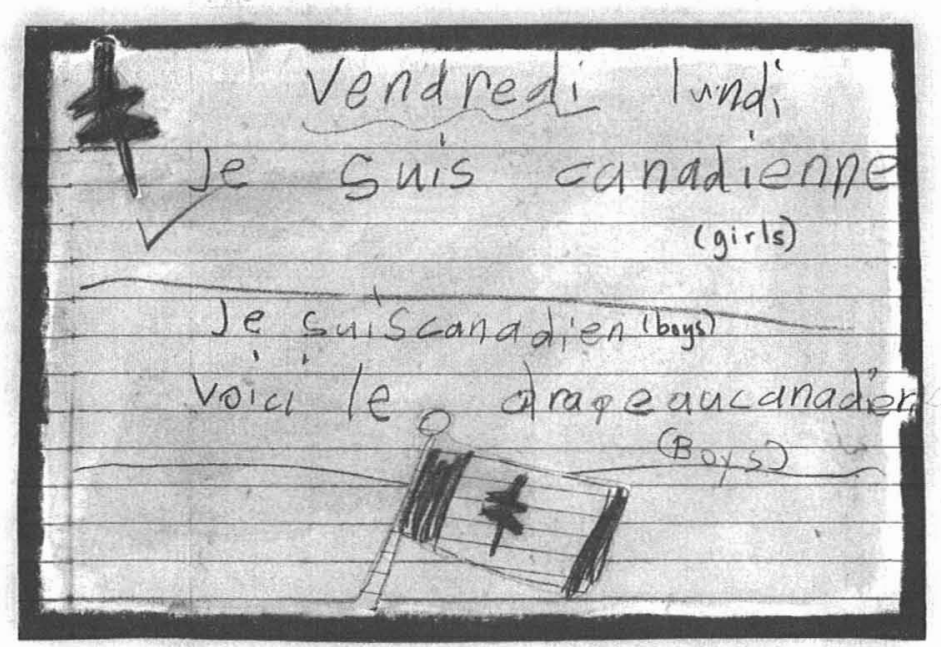

\section{Canada}

I could say it bi-lingually at seven. Or so I

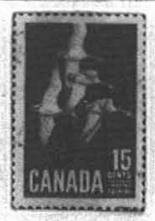
thought, until my French teacher rapped me on the head with a ruler. She taught me that there are gendered ways of being, too. 


\section{Tessera}

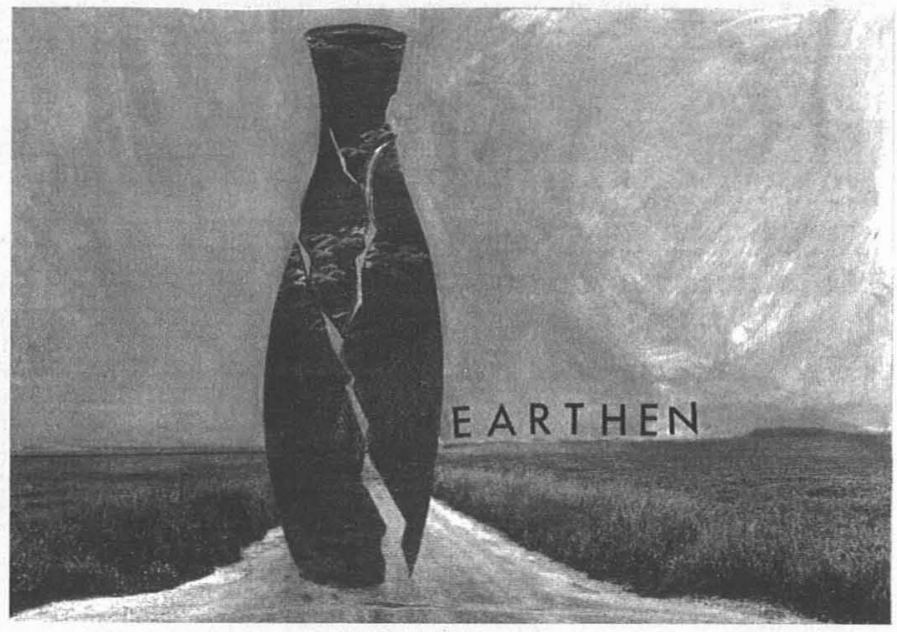

\section{Canada}

Bienvenue au Canada. Now that I have sworn allegiance, secured my papers, $I$ frequently sail right by the checkpoints. Last time I arrived, a group had just landed from Ho Chi Minh City. The customs official looked askance, then trapped a young Vietnamese couple. Waving me on, he opened their luggage, unceremoniously splaying their contents. He broke a ceramic vase he had discovered. Pounding and mincing the porcelain, he proceeded to crush the earth from inside. There was no translator to tell them that he thought they might infect the soil.

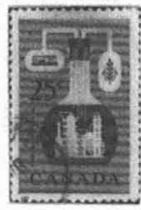




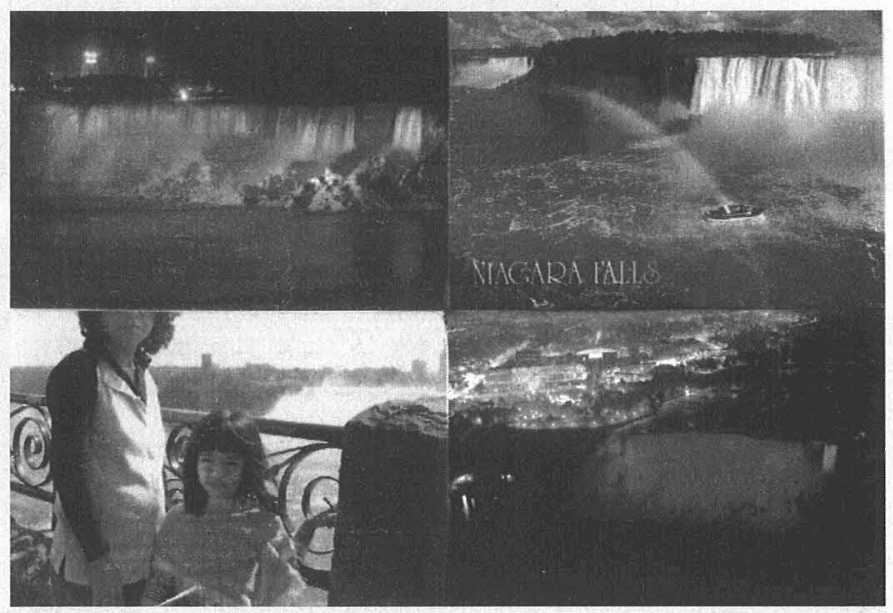

This was the border, until I crossed others. This one, I am told, swirls somewhere in the eddy between that bank and this one. (If you peer through the rotating view finder in the sky tower you can see the whole thing.) I returned last autumn with my lover. We joined tourists wrapped in blue plastic and skimmed the falls on the Maid of the Mist. (Over there, the tourists wear yellow.) We ended our day by watching the evening light show. From a tower on a hill nearby, coloured light disks project every hue imaginable on the falling water. As I watched the crimson arch cascading downwards, I stopped to think about the legend of the 'Indian Maid', whose waterlogged deathbed we trafficked over earlier that day. As we left, we tried to conjure all the other cruise-by stories we'd been told. We stopped at Wendy's for a chocolate shake before heading to our motel.

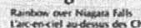

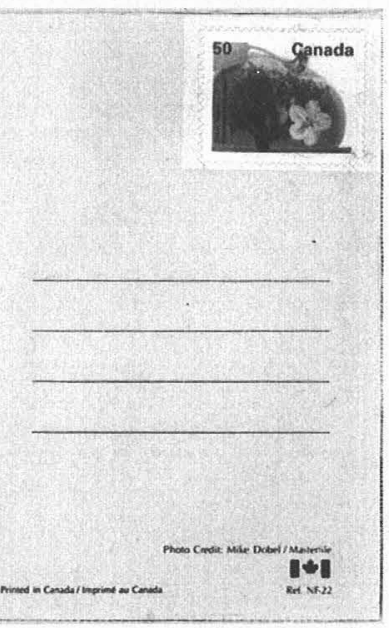

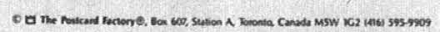

